\title{
SANCTITY IN AMERICA
}

\section{Most Rev. Amleto Giovanni Cicognani}

A "must" book for the library of every Catholic who takes pride in Church and country, this treasury of historical data is now appearing in its third edition. A pageant of apostles, missionaries, founders of religious orders and members of religious communities passes vividly before the reader, beginning with the Jesuit martyrs and Catherine Tekakwitha and ending with Sister Miriam Teresa, extraordinary young novice of our own day. "About the best book known to acquaint Catholics with saintly persons who labored in their own land and might intercede for them with God." -Homiletic and Pastoral Revtew. 272 pp., \$2.00.

Dept. 4-798

\section{St. Anthuma (Build Hroga \\ Paterson 3, New Jersey}

\section{Saint Bernardine of Siena College}

\author{
Conducted by
}

The Franciscan Fathers

$$
\text { of the }
$$

Province of the Most Holy Name of Jesus

A Liberal Arts College Offering
Courses Leading to Degrees in
Arts, Science and Business. Tui-
tion $\$ 8.00$ Per Credit Hour.

Address: Dean of Admissions

Loudonville, New York 